\title{
Hubungan Index Masa Tubuh dan Masa Kerja dengan Keluhan Muskoloskeletal pada Pekerja Instalasi Binatu di Rumah Sakit X
}

\author{
Rini Puspita Dewi ${ }^{1^{*}}$ \\ ${ }^{1}$ Institut Medika Drg Suherman \\ * Correspondence author: rini.poespita@gmail.com ; Tel.: - \\ Received: 27 Agustus 2019; Accepted: 26 September 2019; Published: 28 September 2019
}

\begin{abstract}
Background: Musculoskeletal symtoms is tissue damage in skeletal muscle parts (joints, ligaments and tendons) which caused the body to receive a static load, or work in awkward postures repeated in a long time. Workers work in the laundry by position standing, bending, and sitting in a long time.

Objective: This research aims to determine working periode and body mass indeks with musculoskeletal symtoms at worker laundry installation in Hospital X.

Method: This research is a quantitative research with a cross sectional design. The subjects of research were laundry worker as much as 33 people. Data collection using questionnaire which containing question about musculoskeletal symtoms.

Result: The result of the research shows that working period is significantly related to musculoskeletal symptoms.

Conclusion: The result of this research shows that are significant relationships between working period with musculoskeletal symptoms

Keywords: Musculoskeletal Symptoms, Working Periode, Body Mass Indeks

\section{Pendahuluan}

Kerusakan jaringan pada bagian otot skeletal karena tubuh menerima beban statis, atau bekerja dengan postur janggal yang dilakukan berulang-ulang dalam jangka waktu yang lama disebut keluhan muskuloskeletal. Banyak tempat kerja yang dapat menyampaikan berapa banyak karyawan yang cuti sakit selama waktu tertentu, tetapi bisa menentukan berapa banyak orang yang cuti karena menderita keluhan musculoskeletal (1). Faktor penyebab terjadinya keluhan muskuloskeletal dibagi menjadi tiga faktor risiko yaitu faktor risiko pekerjaan, faktor risiko individu dan faktor risiko lingkungan. Faktor risiko pekerjaan meliputi faktor risiko postur tubuh, beban kerja, frekuensi dan durasi. Faktor karakteristik individu meliputi masa kerja, usia pekerja, merokok, jenis kelamin, kebiasaan olahraga dan Antropometri.
\end{abstract}


Di Uni Eropa gangguan muskuloskeletal adalah masalah kesehatan yang umum terjadi pada pekerja. Pekerja di Eropa mengeluh sakit punggung sebesar 25-27 \% dan sebanyak 23\% mengeluh nyeri otot. The Labour Force Survey melaporkan bahwa diperkirakan sebanyak 539.000 pekerja di inggris menderita keluhan yang disebabkan oleh pekerjaan mereka saat ini maupun pekerjaannya sebelumnya dalam waktu 12 bulan terakhir.

Penelitian pada pekerja laundry tentang sikap kerja dan risiko musculoskeletal disorders (2). Penelitian ini dilakukan dengan sampel sebanyak 150 orang yang masing-masing bagian diambil sebagai sampel sebanyak 30 orang, meliputi bagian penimbangan, pencucian, pengeringan, penyetrikaan dan pengemasan. Hasil penelitian menunjukkan bahwa sikap kerja yang berhubungan dengan keluhan MSDs hanya terdapat pada bagian pencucian. Sebanyak 24 orang (80\%), sikap kerja yang tidak ergonomis mayoritas (60\%) pada bagian pencucian, usia yang paling berisiko pada bagian pengemasan, masa kerja mayoritas kurang dari 6 tahun untuk semua bagian, beban kerja mayoritas pada rentang ringan sampai sedang. Pada bagian pencucian sering kali pekerja bekerja dengan posisi tubuh membungkuk. Sikap kerja yang tidak alami antara lain punggung terlalu membungkuk, pergerakan tangan terangkat, tangan diatas kepala, menjinjing beban satu kg dengan satu tangan, dan bekerja dalam posisi jongkok. Postur kerja seperti ini akan meningkatkan beban kerja otot sehingga jumlah tenaga yang dibutuhkan akan lebih besar (3). Pekerja yang bekerja dengan postur yang berisiko tinggi dalam waktu yang lama ini akan mengalami keluhan muskuloskeletal terutama pada leher dan pergelangan tangan. Pekerja banyak berkerja dengan posisi membungkuk.

\section{Metode}

Penelitian ini merupakan jenis penelitian kuantitatif dengan rancangan crosssectional yang bertujuan untuk mengetahui hubungan antara faktor individu dengan keluhan muskuloskletal pada pekerja instalasi binatu Rumah Sakit X yang dilakukan pada bulan januari sampai mei tahun 2019. Sampel penelitian berjumlah 33 orang. Sampel diambil menggunakan total sampling dengan kriteria inklusi yaitu; sehat, tidak sedang cuti saat penelitian berlangsung, jenis kelamin laki - laki dan perempuan, dan bersedia dijadikan subyek penelitian. Kriteria eksklusinya adalah sedang sakit. Pengambilan data dilakukan dengan menggunakan kuesioner dan melalui observasi. Keluhan Muskuloskeletal diukur dengan menggunakan kuesioner Nordic Body Map. Metode penilaian status gizi responden dengan menghitung perbandingan Berat Badan (BB) dengan Tinggi Badan (TB). Analisis data dilakukan dengan menggunakan uji chi square, untuk menganalisis hubungan bivariat. 


\section{Hasil penelitian}

Tabel 1. Karakteristik muskoloskeletal dengan frekuensi pekerja

\begin{tabular}{llcc}
\hline No & Karakteristik & $\begin{array}{c}\text { Frekuensi } \\
\text { (orang) }\end{array}$ & \% \\
\hline $\mathbf{1}$ & Keluhan Muskuloskeletal & 18 & \\
\hline & Ya & 15 & 55,45 \\
\hline & Tidak & & \\
\hline $\mathbf{2}$ & IMT & 23 & 69,54 \\
\hline & Normal & 10 & 30,30 \\
\hline & Tidak Normal & & \\
\hline $\mathbf{3}$ & Masa Kerja & 13 & 39,39 \\
\hline & <10 Tahun & 14 & 42,42 \\
\hline & 10-20 Tahun & 6 & 18,18 \\
\hline & $>$ 20 Tahun &
\end{tabular}

Berdasarkan hasil penelitian dapat diperoleh bahwa sebagian besar pekerja mengalami keluhan muskuloskeletal. Pekerja yang mengalami keluhan muskuloskeletal sebanyak 18 orang $(54,55 \%)$, sedangkan pekerja yang tidak mengalami keluhan muskuloskeletal sebanyak 15 orang $(45,45 \%)$. muskuloskeletal. Pekerja yang bekerja kurang dari 10 tahun sebanyak 13 orang (39,39\%), pekerja yang bekerja 10-20 tahun sebanyak 14 orang $(54,54 \%)$ dan pekerja yang bekerja $>20$ tahun sebanyak 6 orang $(18,18 \%)$. Masa kerja yang paling lama adalah 32 tahun dan masa kerja yang tersingkat adalah 1 tahun.

Berdasarkan hasil penelitian diperoleh bahwa pekerja dengan IMT normal sebanyak 23 orang $(69,70 \%)$ dan pekerja dengan IMT tidak normal sebanyak 10 orang (30,30\%). Hal ini menunjukkan bahwa sebagian besar pekerja di instalasi laundry memiliki IMT normal.

\section{Pembahasan}

Berdasarkan hasil observasi pekerja sering mengalami keluhan muskuloskeletal malam hari setelah bekerja dan pada saat selesai melakukan pekerjaan. Pekerja juga mengeluhkan sakit saat melakukan pekerjaan, keluhan ini dikeluhkan oleh pekerja. Berdasarkan analisis bivariat antara masa kerja dengan keluhan muskuloskeletal dengan menggunakan uji man whitney diperoleh nilai $p$ yaitu 0,008 , karena nilai $p$ lebih kecil dari 0, 05 maka hal ini berarti bahwa Ha diterima dan Ho ditolak. Jadi dapat disimpulkan bahwa ada hubungan antara masa kerja dengan 
keluhan muskuloskeletal. Hal ini menunjukkan bahwa terdapat hubungan antara masa kerja dengan keluhan.

Analisis bivariat antara IMT dengan keluhan muskuloskeletal dengan menggunakan uji Fisher's Exact Test diperoleh nilai $p$ 1,00 $(p>0,05)$. Hal ini berarti bahwa berarti bahwa Ha ditolak dan Ho diterima. Jadi dapat disimpulkan bahwa tidak ada hubungan yang signifikan antara IMT dengan keluhan muskuloskeletal.

Penelitian yang dilakukan pada pekerja pabrik menunjukkan bahwa terdapat hubungan yang signifikan antara IMT dengan keluhan muskuloskeletal(4). IMT memliki kontirbusi yang tidak cukup besar dan pengaruhnya kecil. Sebagian besar pekerja di instalasi binatu memiliki IMT normal. Hal ini karena karakteristik pekerjaan di instalasi binatu yaitu pekerjaan yang membutuhkan tenaga yang besar dan termasuk dalam aktivitas fisik berat. Hal ini mungkin menyebabkan sebagian besar IMT pekerja normal. tubuh yang tinggi pada umumnya mempunyai bentuk tulang yang langsing sehingga secara biomekanik rentan terhadap beban tekan dan rentan terhadap tekukkan (5).

Berat Badan dengan kategori berlebih (overweight) akan menimbulkan risiko terjadinya nyeri punggung bawah karena beban pada sendi penumpu badan akan semakin meningkat, sedangkan kondisi underweight akan meningkatkan risiko terjadinya nyeri punggung bawah karena seseorang akan kekurangan energi untuk melakukan aktivitasnya sehingga fungsi sistem muskuloskeletalpun akan menjadi terganggu. Penelitian lain menunjukkan bahwa obesitas memiliki hubungan yang erat dengan terjadinya nyeri punggung bawah. Berat beban yang harus diangkat orang dewasa dengan berat badan normal orang adalah $23 \mathrm{Kg}$ dengan pekerjaan yang tidak dilakukan secara berulang (6).

Semakin lama seseorang bekerja maka akan semakin besar juga dampak paparan bahaya di tempat kerja (7). Masa kerja merupakan faktor risiko yang mempengaruhi timbulnya Musculoskeletal Disorders, terutama untuk jenis pekerjaan yang memerlukan kekuatan otot yang tinggi. timbulnya nyeri pada punggung bawah. Masa kerja merupakan faktor risiko dari keluhan muskuloskeletal, karena keluhan muskuloskeletal yang berkaitan dengan pekerjaan bersifat kumulatif(7). Keluhan pada sistem muskuloskeletal hampir tidak pernah terjadi secara langsung, tetapi terjadi akibat suatu akumulasi tekanan atau benturan-benturan kecil maupun besar yang terjadi secara terus menerus dan dalam waktu yang lama, bisa dalam hitungan hari, bulan dan tahun. Waktu terjadinya keluhan tergantung dari pekerjaan apa yang dilakukan oleh pekerja. 
Masa kerja dapat mempengaruhi kinerja baik positif maupun negatif. Memberi pengaruh positif apabila dengan semakin lamanya masa kerja semakin berpengalaman dalam melaksanakan tugasnya. Masa kerja dapat menentukan keahlian seseorang. Pekerja dengan masa kerja lama akan memahami metode kerja yang aman. Pemahaman cara kerja yang aman akan mengurangi pengaruh-pengaruh negatif terhadap tubuh. Masa kerja memiliki pengaruh negatif apabila semakin lama seseorang dalam bekerja, maka semakin banyak terpapar bahaya yang ditimbulkan oleh lingkungan kerja tersebut (7).

\section{Kesimpulan}

Hasil penelitian menunjukkan bahwa terdapat hubungan yang signifikan antara masa kerja dengan keluhan muskuloskeletal pada pekerja instalasi binatu Rumah Sakit X, sedangkan variabel IMT tidak memiliki hubungan yang signifikan dengan keluhan muskuloskeletal. 


\section{Daftar Pustaka}

1. Tarwaka. (2015) Keselamatan Kerja, Kesehatan Kerja, dan Ergonomi dalam Prespektif Bisnis. Surakarta: Harapan Press

2. Ulfah, N., Harwanti, S., dan Nurcahyo, P. J. (2014) Sikap Kerja dan Risiko Musculoskeletal Disorders pada Pekerja Laundry. Jurnal Kesehatan Masyarakat Nasional. Vol. 8 No. 7, Hal. 313-318.

3. Kurniawidjaja, L. M. (2010) Teori dan Aplikasi Kesehatan Kerja. Jakarta: UI Press.

4. Silva, I. M., Santos R., Abreu S., dan Mota, J. (2013) Associations between Body Mass Index and Musculoskeletal Pain and Related Symptoms in Different Body Regions among Workers. Jurnal of Social Sciences. Vol. 3 No. 2, Hal. 1-6.

5. Tarwaka. (2011) Ergonomi Industri: Dasar-Dasar Pengetahuan Ergonomi dan Aplikasi di Tempat Kerja. Surakarta: Harapan Press.

6. ILO. 2013. The Prevention of Occupational Diseases. Geneva: International Labour Organization

7. Suma'mur, P. K. (2013) Higiene Perusahaan dan Kesehatan Kerja. Jakarta: CV. Sagung Seto 